\title{
Functions of the intermediate filament cytoskeleton in the eye lens
}

\author{
Shuhua Song, ${ }^{1}$ Andrew Landsbury, ${ }^{2}$ Ralf Dahm, ${ }^{3}$ Yizhi Liu, ${ }^{4}$ Qingjiong Zhang, ${ }^{4}$ and Roy A. Quinlan ${ }^{2,5}$ \\ ${ }^{1}$ Center for Ophthalmic Research/Surgery, Brigham and Women's Hospital, and Department of Ophthalmology, Harvard Medical School, Boston, \\ Massachusetts, USA. ${ }^{2}$ School of Biological and Biomedical Sciences, Durham University, Durham, United Kingdom. \\ ${ }^{3}$ Centro Nacional de Investigaciones Oncológicas, Madrid, Spain. ${ }^{4}$ State Key Laboratory of Ophthalmology, Zhongshan Ophthalmic Center,

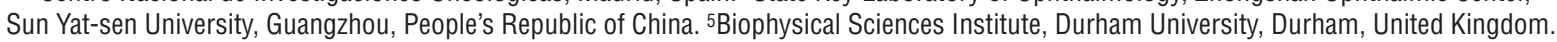

\begin{abstract}
Intermediate filaments (IFs) are a key component of the cytoskeleton in virtually all vertebrate cells, including those of the lens of the eye. IFs help integrate individual cells into their respective tissues. This Review focuses on the lens-specific IF proteins beaded filament structural proteins 1 and 2 (BFSP1 and BFSP2) and their role in lens physiology and disease. Evidence generated in studies in both mice and humans suggests a critical role for these proteins and their filamentous polymers in establishing the optical properties of the eye lens and in maintaining its transparency. For instance, mutations in both BFSP1 and BFSP2 cause cataract in humans. We also explore the potential role of BFSP1 and BFSP2 in aging processes in the lens.
\end{abstract}

\section{Intermediate filaments: a dynamic filament network essential to cell function}

The cytoskeleton comprises three major filament systems - microfilaments, microtubules, and intermediate filaments (IFs). IFs were first identified in Howard Holtzer's laboratory in 1968 (1) as polymers differing from microfilaments and microtubules in that they are $10 \mathrm{~nm}$ in diameter, intermediate in size between microtubules $(25 \mathrm{~nm})$ and microfilaments $(6 \mathrm{~nm})$. The name "intermediate" stuck to describe this defining characteristic of IFs. They are the most resilient component of the cytoskeleton, which initially focused attention on the structural roles played by these filaments in cells. This focus helped us understand how individual cells are integrated into tissues via their IFs, but now we are beginning to appreciate the role played by IFs in other cellular processes such as signaling (2). The eye lens is an example of a tissue in which precise cell-cell organization (Figures 1 and 2) is critical to its function, which is to refract photons onto the retina and help produce a focused image via accommodation of the lens. As we discuss here, the lens-specific IFs, also known as beaded filaments, contribute to this cellular organization, and their disruption compromises lens function in vision.

\section{The eye lens and the visual system of vertebrates}

An optically clear visual apparatus is essential for vision. In vertebrates, the components of this apparatus are the cornea (the major refractive surface of the eye), the lens (which focuses the incoming light), the vitreous (a gel-like substance filling the proximal part of the eye), the inner retina, and the photoreceptors of the outer retina. For light to pass along this visual axis undisturbed, highly ordered cellular and tissue structures are required. Any disturbance in normal cell structure and cell-cell relationships will lead to diffraction, absorbance, or reflection of the light, resulting in disturbed or diminished vision. When this occurs in the eye lens, the condition is referred to as cataract

Conflict of interest: The authors have declared that no conflict of interest exists. Nonstandard abbreviations used: AQP0, aquaporin 0; BFSP1, beaded filament structural protein 1; BFSP2, beaded filament structural protein 2; IF, intermediate filament.

Citation for this article: J. Clin. Invest. 119:1837-1848 (2009). doi:10.1172/JCI38277. and is identified by a loss of transparency and the appearance of light-scattering regions in the lens that are visible upon slit lamp examination. This is the reason why the cellular organization in the lens is so important.

The lens of the eye is avascular and separated from the eye humors that bathe the lens by the lens capsule, a smooth, transparent basement membrane made mainly of type IV collagen and sulfated glycosaminoglycans. The anterior of the lens has a single layer of simple epithelial cells located between the anterior lens capsule and the outermost layer of lens fiber cells (Figure 1). One function of these epithelial cells is to serve as the reservoir of cells from which the lens grows during development and throughout life. The bulk of the lens is composed of lens fiber cells. These cells are formed from the epithelial cells at the lens equator by differentiation, a process that involves the degradation of all membrane-bound intracellular organelles and the expression of lens fiber cell-specific proteins, including the $\beta$ - and $\gamma$-crystallins (3); plasma membrane proteins such as aquaporin 0 (AQP0; ref. 4) and connexin 50 (5); and the lens-specific IF proteins, beaded filament structural protein 1 (BFSP1) and BFSP2 (which are also known as filensin and CP49, respectively) (6). Mature lens fiber cells are long, ribbon-like cells that stretch lengthwise from the posterior to the anterior poles of the lens. Where the apical ends of the fiber cells contact each other, a "suture" is visible. Similarly, at the posterior pole, sutures are formed where the basal ends of the elongated fiber cells meet. In the human, the geometrical arrangement of the fiber cells in the lens means that there are Y-shaped sutures at both the anterior and posterior poles (Figure 1), but this suture pattern can be different for the lenses of other vertebrate species, reflecting the specific growth patterns of the lens fiber cells (7). Since the lens is a closed system and newly differentiating fiber cells form on top of older layers, the oldest lens cells are located at the very center of the lens, termed the lens nucleus (Figure 1). These cells were formed around $2-3$ months after conception (8). The fact that mature lens cells cannot synthesize new proteins means that they contain some of the oldest proteins in our bodies (9). Recently formed lens fiber cells show a characteristic hexagonal cross-section (Figures 1 and 2), which ensures the most optimal packing of these cells at this point in the lens (10). 


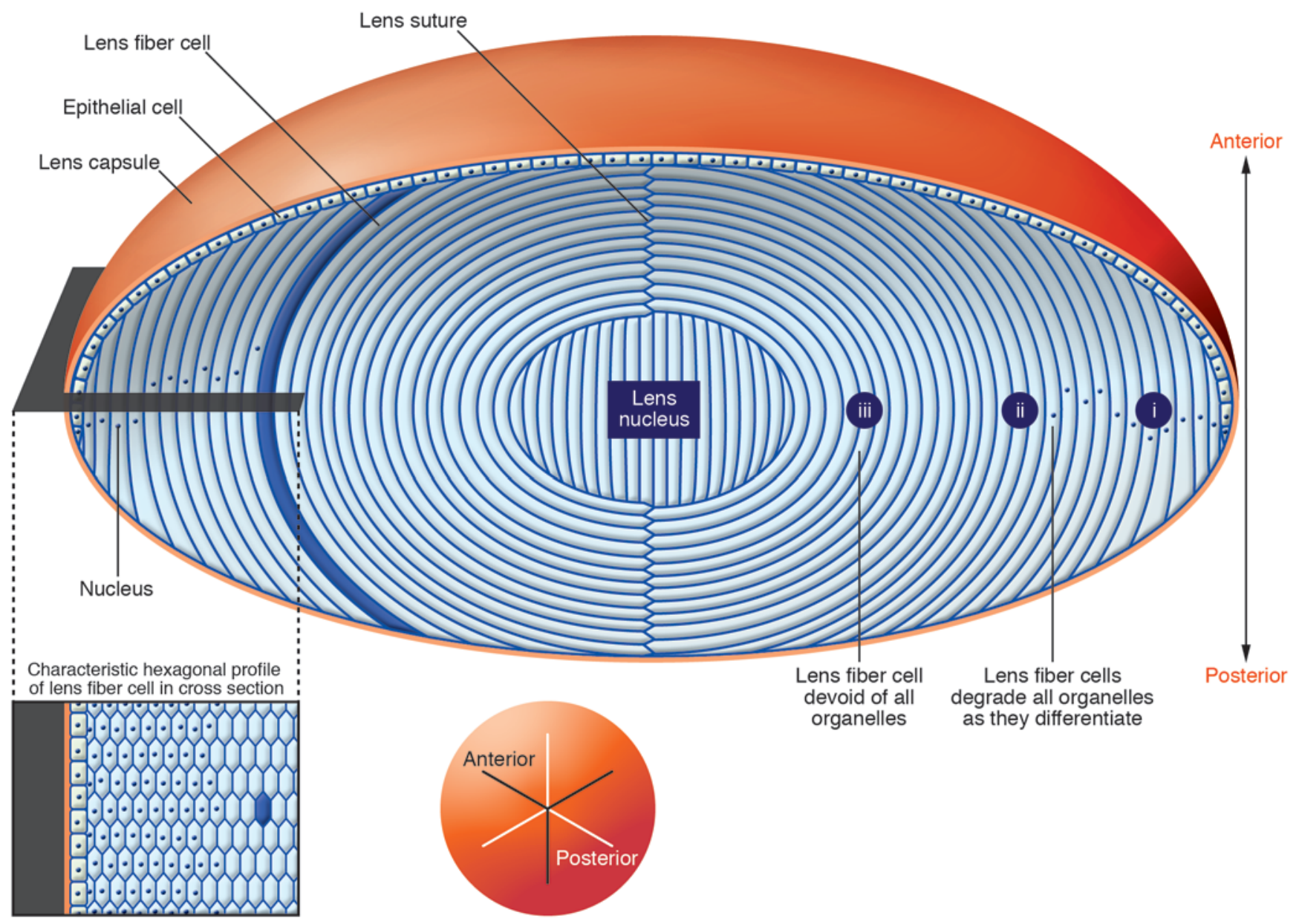

Figure 1

Schematic of the lens and its cellular organization. The lens capsule defines the lens perimeter. The anterior of the lens comprises a single layer of epithelial cells, which contains putative stem cells (108). At the lens equator, epithelial cells differentiate into fiber cells (i-iii). Those fiber cells found in the very center of the lens, a region called the lens nucleus, are derived from the posterior epithelial cells of the lens vesicle. Thereafter, the lens grows by the addition of secondary lens fiber cells formed by the differentiation of epithelial cells located at the lens equator. In humans, this begins between weeks 7 and 8 (Carnegie stage 22) after fertilization. This process goes on throughout life in all vertebrates. The epithelial cells differentiate into hexagonal lens fiber cells at the lens equator to maximize cell-cell contacts with neighboring cells (10). It also requires dramatic cell elongation. When corresponding apical and basal ends from opposing fiber cells of the same age from a neighboring lens sector make contact, lens sutures are formed. The geometry of the lens and the arrangement of the lens fiber cells in the human lens into three segments results in Y-shaped sutures, but offset by $60^{\circ}$ at each pole. One fiber cell profile has been highlighted (dark blue). Lens fiber cells degrade all their organelles, including mitochondria and nuclei (dots) during differentiation (ii). The bulk of the lens thus consists of long, ribbon-like fiber cells devoid of cytoplasmic organelles (iii). In cross-section, cortical fiber cells show a characteristic hexagonal profile. Diagram adapted with permission from Investigative Ophthalmology \& Visual Science (109).

\section{IF proteins in the eye lens}

The mammalian eye lens expresses a surprisingly large number of IF proteins during development and subsequently during lens cell differentiation in the adult lens (summarized in Table 1). These include BFSP1 and BFSP2 (11), vimentin (12, 13), glial fibrillary acidic protein (GFAP) (14), simple epithelial keratins $(14,15)$, nestin $(16,17)$, and synemin $(18)$. Of these, vimentin, BFSP1, and BFSP2 are the most highly expressed and also those that when mutated in humans can cause cataracts $(6,19)$. The lens has traditionally been used as a source for vimentin, and subsequently for BFSP1 and BFSP2, for biochemical analyses (20). Studies on the bovine lens have shown that vimentin is expressed in the lens epithelial and fiber cells, although it is lost from the central fiber cells $(12,21)$, whereas neither beaded filament structural protein is expressed in the epithelial cells of the adult lens, but both are found in all fiber cells (21). The observation that a mixture of BFSP1 and BFSP2 can assemble into 10-nm filaments in vitro (Figure $3 \mathrm{~A}$ ) and that both proteins $(22,23)$ have primary sequences similar to those of other IF family members led to their inclusion as bone fide members of the family of IF proteins (24).

One of the functions of the IFs in cell types other than lens cells is to provide mechanical support to help resist the physical, environmental, and biochemical stresses encountered by cells and tissues (25). Mutations in IF proteins cause a wide range of human diseases. Through the study of these diseases, it has become apparent that IFs are also intimately linked into intracellular scaffold- 

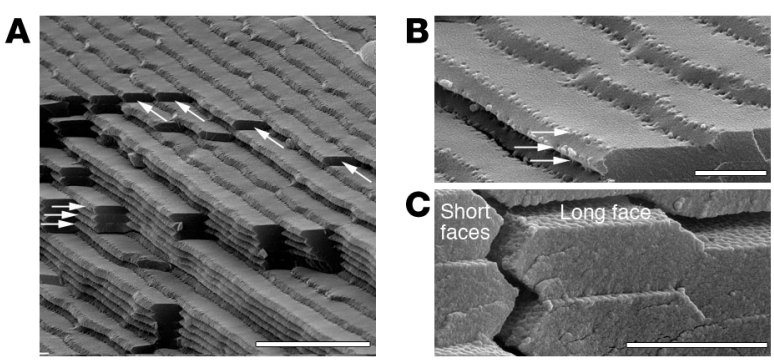

\section{Figure 2}

Scanning electron micrographs of bovine lens fiber cells. The images illustrate the ordered packing of these cells $(\mathbf{A}-\mathbf{C})$, their hexagonal profile with two longer and four short faces $(\mathbf{C})$ to each cell, and the membrane protrusions at the apex of each short face (B, arrows). Each fiber cell in the outermost layers of the lens is precisely aligned with its neighbors (A, arrows). In cross section, the honeycomb appearance of each fiber cell facilitates tight packing to adjacent cells, thus minimizing intercellular spaces and reducing light scatter. Lens fiber cells are highly elongated, each fiber cell extending from the anterior to posterior pole of the lens, with the length being in excess of $10^{4} \mu \mathrm{m}$ (see Figure 3). This means that in addition to being elongated, lens fiber cells are also polarized, with distinct apical (anterior-located) and basal (posterior-located) ends. To ensure the correct interdigitation of neighboring fiber cells, there are plasma membrane protrusions concentrated at the apices of the short faces of lens fiber cells (B, arrows). These are most easily seen when the fracture plane has exposed successive layers of fiber cells (B). At high magnification, a regular pattern is seen on the plasma membranes comprising the long faces of the lens fiber cell hexagonal profile. At a molecular level, these surfaces contain the two different plasma membrane complexes, with $\mathrm{N}$-cadherin and cadherin-11 complexes located on the shorter faces and the periplakin, periaxin, ezrin, and desmoyokin complex concentrated along the long face (C) (68). Scale bars: $50 \mu \mathrm{m}, 20 \mu \mathrm{m}$, and $20 \mu \mathrm{m}$ in A, B, and C, respectively.

ing and transport machineries as well as important signaling pathways that determine cell survival and cell death (25). Mutations in IF proteins often lead to the formation of IF-based aggregates (25). These can compromise the proteasome activity of cells and also be "remembered" by the cell via protein chaperones (26). IFs provide a scaffold for both protein chaperones (27) and the proteasome (28) as well as stress-activated kinases (29), linking the cellular machineries that refold damaged proteins and dispose of irreparable ones to stress signaling pathways (30). It has been through the study of specialized cells and their tissues that we have discovered these exciting aspects of IF function.

As noted above, the eye lens is a highly specialized tissue in terms of its cellular organization $(7,8)$. The plasma membranes of the component fiber cells are very precisely aligned to minimize intercellular spaces (31), and the cytoplasmic protein concentrations are extremely high (>300 g/l; ref. 3 ). It is the beaded filaments that help with the precise cellular organization and, we suggest, through their interactions with protein chaperones, help stabilize the high protein concentrations needed to achieve the high refractive index of the lens (3). Of course, protein crowding (32) is a real risk in the cytoplasm of lens fiber cells, and it is for this reason that the protein chaperones are extremely important for preventing inappropriate protein-protein interactions, protein misfolding, and protein aggregation. Optimization of protein chaperone function through association with the beaded filaments is potentially of great importance for the lens.

\section{Lenticular beaded filaments}

Discovery and inclusion in the IF family. The name "beaded filament" was given to a unique filamentous structure first identified by Harry Maisel and Margaret Perry when they began investigating the cytoarchitecture of the chick lens at the Roslyn Institute in Scotland (33). These filaments had a 5- to 6-nm filament backbone upon which 12 - to $15-\mathrm{nm}$ beads were distributed (Figure 3B). The identity of the beads at that time was unknown, but these are now thought to be associated $\alpha$-crystallin particles (34) (Figure 3B). Through the 1980s, Maisel and his group pioneered the biochemical characterization of the chicken lens beaded filament fraction (35) and subsequently found beaded filaments in mammalian lenses as well (36). Morphologically similar structures immunologically related to mammalian beaded filament proteins were also identified in other chordate lenses (37), suggesting that the beaded filament is a structure that is fundamental to lens function in this phylum. The publication of the first cDNA sequence for rat Bfsp1 (22) and the first complete cDNA sequence for chicken BFSP2 (38) confirmed their inclusion within the IF family. During the same decade, other cDNA sequences (39-41) and gene structures $(42,43)$ were published for BFSP1 and BFSP2, affirming this categorization, but beaded filament proteins are usually assigned to an "orphan" group within the IF protein family (e.g., ref. 25) because of their unusual sequence characteristics (Figure 4). For instance, chick BFSP2 (38), like all mammalian BFSP2 proteins, lacks the C-terminal domain characteristic of nearly all other IF proteins. It is also alternatively spliced to give a minor splice variant with a significantly extended helix 1B. Helix 2 in BFSP1 (filensin) is also truncated compared with other IF proteins, including BFSP2, at least for those species for which sequences are currently available in the NCBI and Ensembl databases. Both BFSP1 and BFSP2 have distinct LNDR and TYRKLLEGE motifs (6) that set them apart from all other IF proteins, especially when other unusual sequence features (Figure 4) are taken into account. It is the combination of these unusual sequence features that likely give BFSP1 and BFSP2 their specific assembly and structural features.

Beaded filaments: their in vitro assembly characteristics. Neither BFSP1 nor BFSP2 appear capable of assembling alone into IFs in vitro $(34,44)$. Rather, they must be mixed with each other to form filaments (Figure $3 \mathrm{~A}$ ). While the assembled proteins form a $10-\mathrm{nm}$ filament with a regular beaded modulus along its length (45), these moduli are structurally different from the beads observed on native beaded filaments either isolated from

\section{Table 1}

Summary of the IF proteins expressed in the developing and adult mammalian lens

\begin{tabular}{|c|c|c|c|c|}
\hline \multirow[t]{2}{*}{ IF protein } & \multicolumn{2}{|c|}{ Developing lens } & \multicolumn{2}{|c|}{ Adult lens } \\
\hline & Epithelium & Fibers & Epithelium & Fibers \\
\hline BFSP1 & - & + & - & + \\
\hline BFSP2 & - & + & - & + \\
\hline Vimentin & + & + & + & + \\
\hline GFAP & + & - & + & - \\
\hline K8/K18/K19 & + & - & + & - \\
\hline Nestin & + & + & - & - \\
\hline Synemin & + & + & + & + \\
\hline
\end{tabular}

GFAP, glial fibrillary acidic protein; K, keratin; +, present; -, absent. 

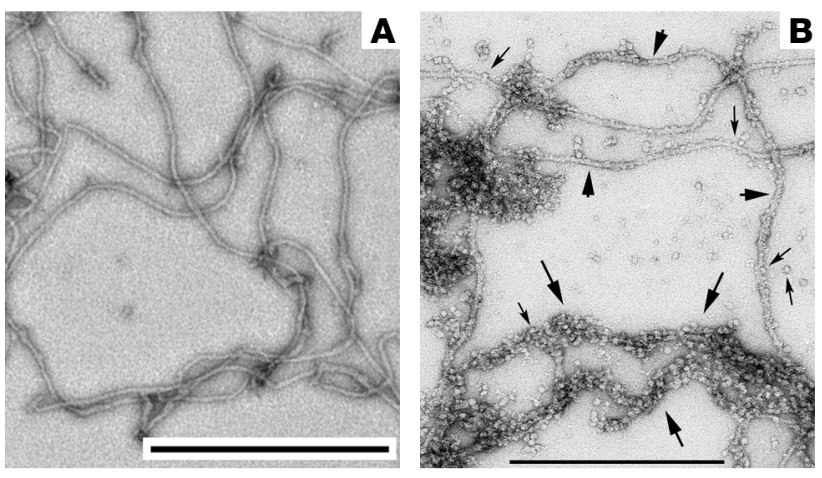

Figure 3

Assembly and sequence characteristics of BFSP $1 / 2$ filaments and native beaded filaments. (A) The micrograph shows that in vitro, human BFSP2 and bovine BFSP1 form 10-nm filaments when mixed together at a molar ratio of 2:1. The human BFSP2 was produced recombinantly, while the BFSP1 was purified from bovine lenses. In the absence of $\alpha$-crystallins, the BFSP1 and BFSP2 proteins form 10-nm filaments, supporting their inclusion in the IF superfamily. Both proteins were prepared as described in ref. 20. (B) This micrograph shows the native filaments present in the lens. Two types are apparent: Smooth, 10 -nm filaments (arrowheads) are decorated with $\alpha$-crystallin particles (small arrows). Beaded filaments (large arrows), which also contain $\alpha$-crystallin particles, are much more abundant and appear untidy in their association with the supporting filament, to the extent that the filament backbone is almost totally obscured. By comparison, the 10-nm filaments are instantly recognizable despite being decorated with $\alpha$-crystallin particles. These beaded filaments are the structures first described by Maisel and Perry as being lens specific, and it is from these that filensin and CP49 derive the names BFSP1 and BFSP2, respectively. Scale bars: $500 \mathrm{~nm}$.

the lens (Figure 3B) or seen in thin sectioned filaments (e.g., refs. 37,46 ). The inclusion of $\alpha$-crystallin (complexes of both $\alpha \mathrm{A}$ and $\alpha \mathrm{B}$-crystallin proteins) with BFSP1 and BFSP2 during in vitro assembly can result in filaments morphologically similar to the native beaded filament (34). The morphology of both the reconstituted (34) and native beaded filaments (Figure $3 \mathrm{~B}$ ) is quite distinct from the that of the 10-nm filaments assembled in vitro from mixtures of BFSP1 and BFSP2 alone. This might suggest that the subunit geometry of beaded filament structural proteins 1 and 2 is altered when assembled in the presence of the lens $\alpha$-crystallin, giving the distinctive beaded filament morphology and providing a more efficient scaffold for the association of these very important protein chaperones. Beaded filaments and 10-nm filaments coexist in lens fiber cells (see, for example, Figure 3B). When vimentin was coassembled with $\alpha$-crystallin in vitro, the $\alpha$-crystallin particles were seen to decorate $10-\mathrm{nm}$ IFs and not structures resembling beaded filaments (47). It is therefore reasonable to suggest, but remains to be formally proven, that the $10-\mathrm{nm}$ filaments seen in lens sections and in lens fractions (Figure $3 \mathrm{~B}$ ) primarily comprise vimentin, whereas the beaded filaments comprise BFSP1, BFSP2, and $\alpha$-crystallin. The functional significance of this $\alpha$-crystallin chaperone association with beaded filament structural proteins 1 and 2 remains to be elucidated, but it would seem likely that the unusual sequence characteristics of beaded filament structural proteins 1 and 2 will be key to understanding the structure-function relationships for the beaded filament.

\section{Role of beaded filaments in the eye lens: cataract- causing mutations and mouse knockouts}

The discovery of the first cataract-causing mutations in BFSP2 $(48,49)$ and the observation that targeted deletion of $B f s p 2$ from the mouse genome resulted in loss of optical properties and the eventual appearance of cataract established that beaded filaments are critical to the optical properties of the eye lens (50). When the lens phenotypes of the different mouse knockouts (46, $50-52)$ and the clinical descriptions for the six pedigrees (48, $49,53-56$ ) covering mutations in BFSP1 and BFSP2 (Table 2) are considered, three key messages emerge: first, beaded filaments are essential to the optical properties of the eye lens; second, beaded filaments are critical to lens transparency, and mutations in BFSP1 and BFSP2 can cause cataract; and third, beaded filaments temper the aging of the eye lens. These messages are developed in the next two sections.

Optical properties and transparency of the lens depend upon the beaded filaments. The marked decline in the lens optical properties as a result of $B f s p 2$ knockout in the mouse was a critical observation (50). Ophthalmologists have striven to classify cataract (57), which is the most important lens pathology. This is despite the fact that refraction and lens physical properties change with age and are believed to precede cataract in the human (58). Analysis of $B f s p 2$-knockout mice led us to the conclusion that lens opacification, that is, cataract, was not necessarily the most important indicator of failed lens function. Rather, the loss of the lens optical properties was an equally important phenotype. As an example of this conclusion, myopia can be a dominant eye phenotype associated with the E233del BFSP2 mutation, although a distinct, Y-shaped cataract also typifies this pedigree (ref. 53; see Figure 5). The development of myopia is complex, given the multiple optical components in the eye, but altered lens thickness is a factor in myopia and correlates with its severity (59). Defects in the lens, the cornea, and/or the axial length of the eye are the three main causes of refractive error in the eye (60). Precisely how these three components contribute to the development of myopia is still a matter of debate (e.g., ref. 61). Lens opacification can contribute to refractive error (62). Only one of the three E233del BFSP2 pedigrees has been reported to exhibit myopia, albeit mild (53), and in that family pedigree, there was no evidence supporting the idea that myopia was caused by changes in lens morphology. The myopia in this family is more likely due to image blur caused by the Y-sutural cataract or changes in optical quality. Therefore, it is important to note that only specific types of cataract and lens refractive error may be associated with myopia. The reason for this is yet unknown but likely reflects the change in the optical properties of the lens and its role in the visual pathway. Interestingly one of the identified myopia loci, MYP8 (OMIM 609257), at chromosomal location 3q26 (63), is tantalizingly close to the BFSP2 locus (3q21-25; ref. 64).

The Y-shaped cataract for the E233del mutation in BFSP2 (Figure 5) has its origins in changes to the internal cellular organization of the lens (Figure 1). When the ends of individual lens fiber cells in opposing lens sectors meet, they form the lens sutures at the anterior and posterior poles of the lens (62). The sutures are regions where significant, localized rearrangements of the cytoskeleton occur (65). Any alteration in the organization of the plasma membrane of lens fiber cells due to a changed beaded filament/IF cytoskeleton would be expected to increase light scatter and cause a reduction in, or even loss 


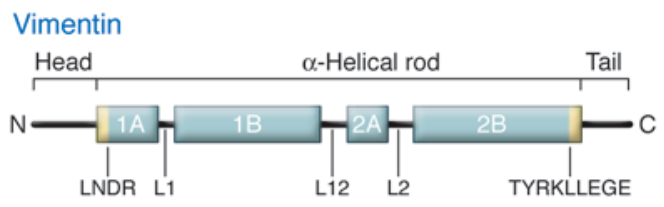

BFSP2

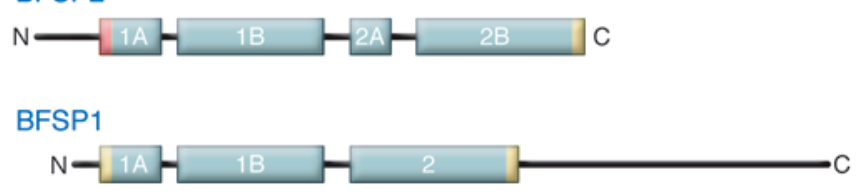

Figure 4

Schematic highlighting the unusual features of the protein domains in BFSP1 and BFSP2. Predicted secondary structure for a typical IF protein (vimentin) compared with that predicted for BFSP2 and BFSP1. IF proteins are composed of an $\alpha$-helical coiled-coil domain flanked by non-helical $\mathrm{N}$ and $\mathrm{C}$ termini. The boxes represent $\alpha$-helical domains, which are separated by non-helical linkers L1, L12, and L2. The yellow boxes at the ends of helix $1 \mathrm{~A}$ and $2 \mathrm{~B}$ represent the highly conserved LNDR and TYRKLLEGE motifs, in which mutations usually seriously disturb IF function. These motifs are changed in mammalian BFSP1 (LGER and RYHRIIEIE, respectively) and BFSP2 (LGGC and SYHALLDRE, respectively). The R-to-C change in the LNDR motif of BFSP2 would actually cause disease if found in, for example, glial fibrillary acidic protein (GFAP) (110), and for this reason the motif is colored red in the schematic. In fact, an R113C mutation causes cataract in mice when introduced into vimentin (87). Clearly, it is the context of such a change that will determine whether this alone will abrogate filament function. The rod domain of BFSP1 is predicted to be 2-3 nm shorter than that of other mammalian IF proteins due to its shorter helix 2. BFSP2 lacks a C-terminal tail as also observed for keratin 19 , a type 1 IF protein.

of, lens transparency (31). Beaded filaments are usually found associated with the plasma membranes of lens fiber cells, but the extent of this association appears dependent upon the differentiation stage of the lens fiber cell (12) and can be influenced by proteolytic fragmentation $(21,63)$ and phosphorylation (66). It is also possible that the redistribution of the beaded filaments requires compliance from the other major IF network in lens cells, namely the vimentin network. Vimentin filaments are also tightly apposed to the lens fiber cell plasma membrane, just like the beaded filaments $(12,21)$. The plasma membranes of the lens fiber cells are also enriched in IF-binding proteins such as plakoglobin $(67)$, plectin $(12,68)$, periplakin (69), and desmoyokin (68). These are all members of the spectraplakin protein family $(70,71)$ and thus share features of both the spectrin and plakin superfamilies; they therefore are proven linkers between the plasma membrane and the cytoskeleton, in particular IFs. These are the most likely candidates to link vimentin and the beaded filament structural proteins to the plasma membrane complexes of lens fiber cells (68).

Other lens-specific proteins, for instance, lengsin (72), which can bind to BFSP2, might also be required in order to alter the membrane association of beaded filaments. Lengsin expression is dramatically increased just when the beaded filaments adopt a more cytoplasmic distribution in lens fiber cells, at the time of the programmed removal of mitochondria, nuclei, and other cellular organelles (73). BFSP1/2 filaments ensure the correct spatial organization of fiber cells in the lens and the optimal plasma membrane profiles of the lens fiber cells (Figure 2), minimizing light scatter and maximizing the optical function of the lens. Removal of $B f s p 2$ by targeted gene knockout disrupts these aspects of lens tissue organization (50), increasing light scatter, as seen by slit lamp analysis $(50,52)$. The lenses of patients with BFSP2 mutations are also reported to show increased light scatter $(49,53,54)$, but it remains to be formally tested whether the lens fiber cell profiles and their spatial organization are disrupted by the presence of either BFSP2 or vimentin (19) mutations in human lenses.

Thus far, only one mutation in BFSP1 has been reported, and it is an autosomal recessive mutation arising from a consanguineous marriage (56). The mutation is predicted to truncate BFSP1 as it deletes 3,343 bases spanning exon 6 , introducing a frameshift from residue 246 in the coding sequence and a premature stop codon. This is predicted to remove most of helix 2 and the entire C-terminal domain of the protein. It is not known whether the RNA produced by the mutated BFSP1 is transcribed or removed by the nonsense-mediated decay RNA surveillance pathway. If it is removed in this manner, however, this would effectively create a BFSP1 knockout in the human to parallel the mouse BFSP1 knockout (74). Indeed, in both cases, the lens phenotype is progressive: light scatter increases with age in the mouse, as does cataract in the human. A similar progressive deterioration in lens function has also been noticed for the mouse Bfsp2 knockout (52) and some human BFSP2 mutations, for example E233del BFSP2 $(49,53,54)$.

The aging lens: accelerated by mutations in beaded filament proteins? The progressive nature of the increased light scatter and cataract development for the mouse $B f s p 1$ and $B f s p 2$ knockouts (52, 74) and the human cataracts caused by BFSP1 (56) and BFSP2 $(49,53,54)$ mutations suggest that there is an aging element to the beaded filament contribution to the optical properties of the lens. BFSP1 is proteolytically processed differently in lens fiber cells at the center compared with those at the periphery (21), and the lens cytoskeleton, including beaded filament proteins, is often targeted by proteolysis during cataract formation $(75,76)$. It is also clear from the targeted knockouts in mice and the autosomal recessive human mutation in BFSP 1 that loss of beaded filaments causes cataracts. Therefore, any increase in the processing of beaded filament proteins, or indeed vimentin (12), which is lost from mature lens fiber cells, could accelerate aging in the lens and/or precipitate cataract formation. There are important changes in the aging human lens involving the formation of a diffusion barrier, which inhibits transport of water and other small molecules into and out of the lens nucleus, around the fifth decade of life, that is thought to contribute to an increase in oxidative damage in the center of the lens (77). While this is a later event in the life of a human being, it is also clear that cataract in later life can be determined by events that occur in the womb (78). Cataract is one of the major risks for visual impairment in the elderly, and there is a clear genetic component (79). Given that mutations in beaded filament structural proteins increase light scatter, it is reasonable to anticipate that beaded filaments will be important factors in determining the detail of age-related cataract, either in the form of polymorphisms that predispose to this disease or even mutations that specifically cause age-related cataract. The proteolytic processing of the beaded filament structural proteins is likely to be a key factor in the etiology of age-related cataract. 
Table 2

Mutations in BFSP1 and BFSP2 and their associated proteins linked to lens cataract

\begin{tabular}{|c|c|c|c|c|}
\hline $\begin{array}{l}\text { Human gene } \\
\text { symbol (OMIM) }\end{array}$ & $\begin{array}{c}\text { Human } \\
\text { chromosomal } \\
\text { Iocation (marker) }\end{array}$ & $\begin{array}{l}\text { Mutation } \\
\text { details }\end{array}$ & Phenotype ${ }^{A}$ & Reference \\
\hline \multicolumn{5}{|c|}{ Cataract-causing mutations in humans } \\
\hline BFSP1 (603307) & $\begin{array}{c}\text { 20p12.1-p11.23 } \\
\text { (D20S860) }\end{array}$ & $\begin{array}{l}\text { Deletion encompassing } \\
\text { exon 6, } \\
\text { c.736-1384_c.957-66 } \\
\text { del - frameshift and } \\
\text { loss of exon 6; recessive }\end{array}$ & Cortical, nuclear progressive & 56 \\
\hline \multirow[t]{2}{*}{ BFSP2 (603212) } & \multirow[t]{2}{*}{$\begin{array}{l}3 \mathrm{q} 21-\mathrm{q} 25 \\
\text { (D3S1292, } \\
\text { D3S2322, } \\
\text { D3S1541) }\end{array}$} & E233del & $\begin{array}{l}\text { Prominent sutures, general lens haze, progression } \\
\text { to lamellar cataract } \\
\text { Myopia; Y-suture cataract } \\
\text { Sutural cataract - progressive } \\
\text { Variable cataract phenotype, but with lamellar } \\
\text { and suture involvement }\end{array}$ & $\begin{array}{l}49 \\
53 \\
54 \\
48\end{array}$ \\
\hline & & $\mathrm{R} 339 \mathrm{H}$ & Lamellar cataracts & 55 \\
\hline VIM (193060) & $10 \mathrm{p} 13$ & E151K & Pulverulent cataract & 19 \\
\hline CRYAA (123580) & $\begin{array}{l}21 \mathrm{q} 22.3 \\
\quad(\mathrm{D} 21 \mathrm{~S} 1912)\end{array}$ & $\begin{array}{l}\text { W9X: recessive } \\
\text { R12C } \\
\text { R21L } \\
\text { R21W } \\
\text { R49C } \\
\text { R54C } \\
\text { G98R } \\
\text { R116C }\end{array}$ & $\begin{array}{l}\text { Cataract } \\
\text { Bilateral nuclear cataract with microcornea } \\
\text { Cataract } \\
\text { Bilateral nuclear cataract with microophthalmia } \\
\text { Nuclear cataract } \\
\text { Bilateral nuclear cataract with microcornea } \\
\text { Punctate opacities, total in homozygote and microcornea } \\
\text { Progressive cataract; from ring-like peripheral to } \\
\quad \text { total cataract } \\
\text { Zonular central nuclear opacities; microophthalmia } \\
\text { Cataract — variable onset and phenotype } \\
\text { Fan-like cataract with microcornea } \\
\text { Cataract-variable phenotype }\end{array}$ & $\begin{array}{c}112 \\
113,114 \\
115 \\
113,114 \\
116 \\
114 \\
117 \\
118 \\
119 \\
120 \\
121 \\
122,123\end{array}$ \\
\hline CRYAB (123590) & $\begin{array}{l}11 \mathrm{q} 22.3-\mathrm{q} 23.1 \\
(\mathrm{D} 11 \mathrm{~S} 1986 \\
\text { D11S908) }\end{array}$ & $\begin{array}{l}\text { P20S } \\
\text { R120G } \\
\text { D140N } \\
\text { del450A } \\
\text { del464CT } \\
\text { Q151X } \\
\text { R157H } \\
\text { A171T }\end{array}$ & $\begin{array}{l}\text { Posterior polar cataract } \\
\text { Cataract and desmin-related myopathy } \\
\text { Lamellar cataract } \\
\text { Posterior polar cataract — no progression } \\
\text { No cataract, myofibrillar myopathy } \\
\text { No cataract, myofibrillar myopathy } \\
\text { No cataract, dilated cardiomyopathy } \\
\text { Lamellar cataract }\end{array}$ & $\begin{array}{l}124 \\
104 \\
125 \\
105 \\
106 \\
106 \\
126 \\
114\end{array}$ \\
\hline *MIP $(154050)$ & $\begin{array}{l}12 q 13 \\
(\mathrm{D} 12 \mathrm{~S} 368 \text { and } \\
\text { D12S1676) }\end{array}$ & $\begin{array}{l}\text { R33C } \\
\text { E134G } \\
\text { T138R } \\
\text { R233K }\end{array}$ & $\begin{array}{l}\text { Total cataract } \\
\text { Polymorphic - cortical but also } \\
\text { suture involvement in some } \\
\text { Polymorphic }\end{array}$ & $\begin{array}{l}101 \\
127 \\
128\end{array}$ \\
\hline \multicolumn{5}{|c|}{ Other proteins shown to interact with beaded filament structural proteins in non-human lenses } \\
\hline ANK2 (106410) & $4 q 25-q 27$ & $\begin{array}{l}\text { Targeted deletion } \\
\text { of mouse Ank2 }\end{array}$ & Cataract & 94 \\
\hline $\begin{array}{l}\text { CRYGB/CRYGC/CRYGE } \\
(123670,123680)\end{array}$ & $2 q 33-q 35$ & $\begin{array}{l}\text { Naturally occurring } \\
\text { or radiation-induced } \\
\text { mutations in mouse } \\
\text { Crygb, Crygc, Cryge }\end{array}$ & Cataract caused by altered aggregation & 103 \\
\hline * GLULD1 (611470) & $6 q 11$ & & & 72 \\
\hline TMOD4 (605834) & $1 q 12$ & & & 95 \\
\hline
\end{tabular}

AFor explanation, see ref. 57. *MIP encodes AQP0; GLULD1 encodes lengsin. ANK2, ankyrin 2; CRYAA, $\alpha A-c r y s t a l l i n ; C R Y A B, \alpha B-c r y s t a l l i n ; ~ C R Y G B$, $\gamma$ B-crystallin; CRYGC, $\gamma$ C-crystallin; CRYGE, $\gamma$ E-crystallin; GLULD1, glutamate-ammonia ligase (glutamine synthase) domain containing 1; MIP, major intrinsic protein of lens fiber; TMOD4, tropomodulin 4; VIM, vimentin. 

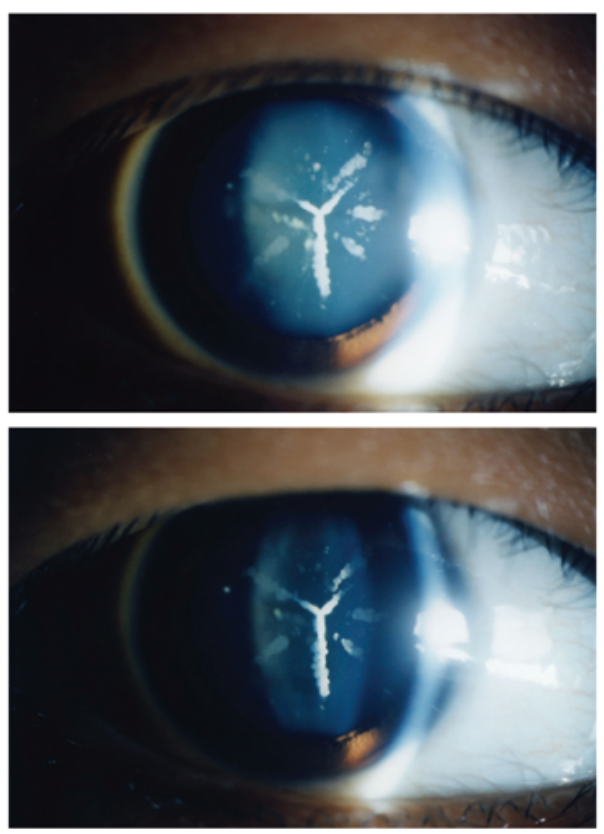

Bfsp2 mutations: compounding factors in the cataract phenotype? Many of the mouse strains currently used to investigate the functions of lens proteins (in particular the 129 and FvB mouse strains, which are commonly used to generate gene knockouts and transgenics, respectively) carry a naturally occurring $B f s p 2$ mutation that effectively removes exon 2 ; the resulting frameshift in exon 3 leads to premature termination of the protein product $(46,51,80)$. It is well known that mouse background can influence the cataract phenotype (as seen for connexinknockout mice, ref. 81; and a $\gamma$ E-crystallin mutant, ref. 82 ). The combination of a subtle loss in optical function with increased light scatter caused by an endogenous $B f s p 2$ mutation and the consequential loss of the beaded filament network $(46,80)$ will therefore have an impact on the interpretation of the cataract phenotypes reported following the knockout, overexpression, or mutation of other lens proteins (80). This also suggests that $B f s p 2$ polymorphisms/mutations are potentially important genetic modifiers of lens phenotypes caused, for example, by gene knockout (e.g., for Lim2; ref. 83), especially in those cases where a biochemical interaction has already been identified (84), as in the case of bovine AQP0. These data suggest that some of the mouse cataract phenotypes reported in the literature might not be due to a monogenic lesion, but could be bi-/multigenic as a result of the naturally present splice site mutation in $B f s p 2$ that is found in many inbred strains of laboratory mouse (46).

\section{Beaded filaments and vimentin: a functional partnership?}

Vimentin-containing IFs play a compensatory role in the Bfsp2knockout mouse model (46). Although Bfsp1 levels are significantly reduced in both published $B f s p 2$ knockouts $(50,52)$, the Bfsp1 that remains can associate with the vimentin filaments, changing their morphology (46). There is also biochemical evidence to support the hypothesis that there is interaction, albeit limited, between BFSP1 and vimentin $(23,34)$. Although mice lacking vimentin do not have a published lens phenotype (85),

\section{Figure 5}

An example of the Y-shaped cataract caused by the E233del BFSP2 mutation. The cataract is typical of the pedigree recently reported with an E233del BFSP2 mutation (53). Notice the white deposits visible in the lenses of this affected individual taken from a previously published pedigree. The white deposits form a $Y$ shape, which is related to the suture pattern made by the abutting apical and basal ends of the lens fiber cells. The different lighting levels (brighter, top panel; less bright, lower panel) accentuate the anterior (bottom panel) and posterior (top panel) sutures and their associated light scattering deposits. Reproduced with permission from Molecular Vision (53).

overexpression of vimentin in the lens causes cataract (86). Recently, the introduction of an Arg-to-Cys mutation in the LNDR motif in helix $1 \mathrm{~A}$ of vimentin produced a dominant negative mutant, and mice transgenic for this mutant developed cataract (87). Further, the first vimentin mutation (E151K) to cause cataract in humans has been identified (19). Therefore, there is little doubt that vimentin is important for lens function. This could be due to disruption of vimentin assembly caused by the E151K mutation or to increased proteasomal activity (19); these would suggest a dominant gain of function as the underlying mechanism in this cataract phenotype.

\section{Beaded filament-associated proteins: candidates for cataract and compromised lens function?}

The identification of mutations in BFSP1 and BFSP2 as a cause of inherited cataract implies that it is important to check for lens phenotypes in patients reported as having mutations in genes encoding any beaded filament- or vimentin-associated proteins that cause disease (see Table 2). Beaded filaments are part of the plasma membrane cytoskeleton complex (88) that can be isolated from lens fiber cells. Underneath the plasma membrane of lens cells is a subplasmalemmal coat of filaments (89), where IF-binding proteins such as plakoglobin (also known as $\gamma$-catenin; ref. 89) and members of the plakin protein family (90) (including periplakin and plectin; ref. 91) are found. Such proteins mediate crosstalk between the actin and IF networks in cells.

Ankyrin has also been identified as a potential linker for vimentin to plasma membranes (92), and it is abundant in the lens (93). The targeted knockout of ankyrin causes cataract in mice (94). In the same study, targeted knockout of neuronal cell adhesion molecule (Nrcam) also resulted in cataract, but prior to this study, $\mathrm{NrCAM}$ was not recognized as a lens protein, and as yet there are no reported direct interactions with IF proteins, although this is a cell-cell junction component. In a similar vein, tropomodulin can also bind to BFSP1 (95), but is better known as an actin-binding protein. Tropomodulin associates with the plasma membranes of 


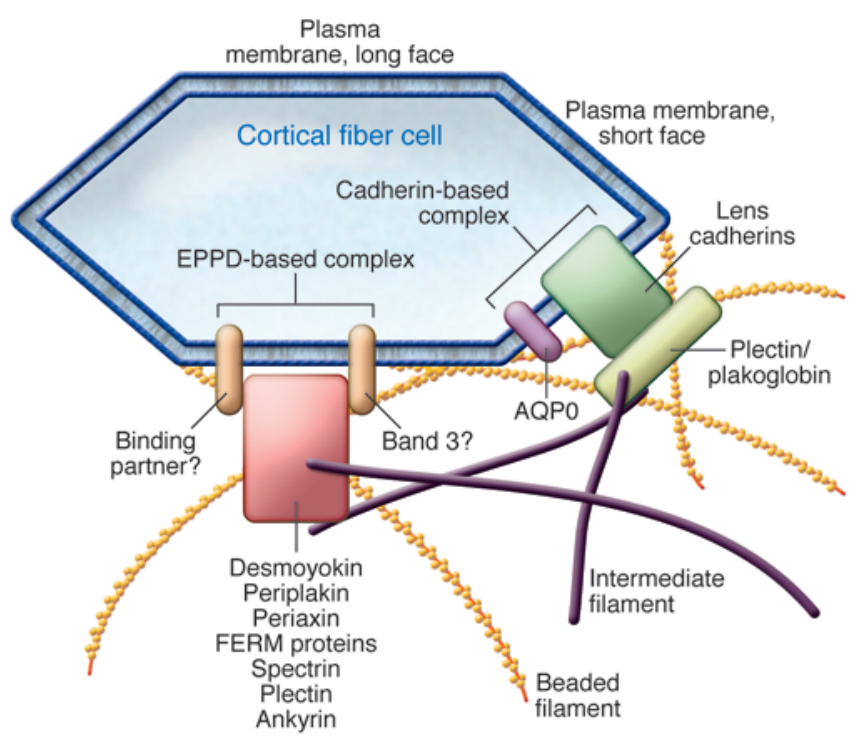

\section{Figure 6}

Schematic showing the links between beaded filaments and IFs at different plasma membrane sites in the lens fiber cell. Beaded filaments interact with the plasma membranes of lens fiber cells and are often tightly associated, resisting even alkali extraction (111). Two different protein complexes have been characterized recently in lens fiber cells (68), termed the cadherin- and EPPD-based (ezrin, periplakin, periaxin, desmoyokin-based) complexes, which associate with the short and long faces of fiber cells (see Figure 2), respectively. Plakoglobin and plectin are potential linkers for the IFs and beaded filaments to the cadherin complex. On the long faces of the fiber cells, a number of potential proteins that would link the IFs and beaded filaments to the plasma membrane have been identified (FERM, ankyrin), but the identity of the transmembrane proteins has yet to be determined. Although CD44 homologs were looked for, none were found (68), but the lens does express band 3 (96), which could link to ankyrin and spectrin. Some details of this lens plasma membrane-cytoskeleton complex might parallel that of the erythrocyte. lens fiber cells when they begin to elongate; so, like ankyrin, it is another actin-binding protein with a plasma membrane location and the potential to bind lens IF proteins.

The lens has highly specialized cell-cell junctions to minimize intercellular spaces and to facilitate the hexagonal honeycomb arrangement of the lens fiber cells. This specialized cell-cell junction has been called the cortex adherens mosaic, and it comprises two different membrane complexes (68). One contains the transmembrane glycoproteins $\mathrm{N}$-cadherin and cadherin-11, which associate with $\alpha$-, $\beta$-, and $\gamma$-catenin (plakoglobin), p120catenin, and vinculin and is found at the short faces of the hexagonal cell profile (Figure 6). The other complex contains periplakin, periaxin, ezrin, and desmoyokin and is found on the longer faces of the hexagonal cell profiles in the lens cortex (Figure 6). It is currently unclear how this complex is linked to the plasma membrane, whether this is by a CD44-like protein (68) or via band 3, which is found in the lens (96). Deletion of N-cadherin by targeted knockout causes microphthalmia and lens fiber cell degenerations, as evidenced by persistent vacuolization, indicating how key this component is to these cellcell junctions and lens formation (97). In contrast, the deletion of periplakin does not apparently result in an overt lens phenotype, as it was not reported in the characterization of the knockout mouse (98). The only evidence to date for a link between the cortex adherens mosaic and cataract is the report of an ERM protein fam- ily member, merlin, mutations in which cause neurofibromatosis type 2 , a disease commonly associated with cataracts (99). This has been reproduced in a mouse model of neurofibromatosis type 2 (100). These plasma membrane proteins are nevertheless important potential interaction partners for lens IFs (Table 3).

In both plasma membrane complexes that constitute the cortex adherens mosaic, there are proteins that associate with vimentin. Recently, one of the vimentin-binding proteins, periplakin, has been shown to bind to beaded filament structural proteins (69), but it is unclear precisely how beaded filaments attach to the lens plasma membranes. It is possible that beaded filaments associate with integral plasma membrane proteins such as AQP0, as both BFSP1 and BFSP2 bind to the C-terminus of AQP0 (84). Mutations in the gene encoding AQP0 also cause autosomal dominant cataract (101), although the consequences for lens beaded filaments have not been reported. Interestingly AQP0 also binds $\gamma \mathrm{E} / \mathrm{F}$-crystallins (102), major lens structural proteins (3) that can also associate with BFSP2 in some cataracts. Bfsp2 was found colocalized with $\gamma$-crystallins in the intranuclear aggregates formed in the lens fiber cells of mice expressing C-terminally truncated $\gamma \mathrm{B}$-crystallin (103). It is conceivable that the amyloid fibrils formed by this mutant $\gamma \mathrm{B}$-crystallin and their associated $\alpha$-crystallins caused Bfsp 2 to be concentrated in the lens fiber cell nuclei. The fact that beaded filaments are naturally complexed

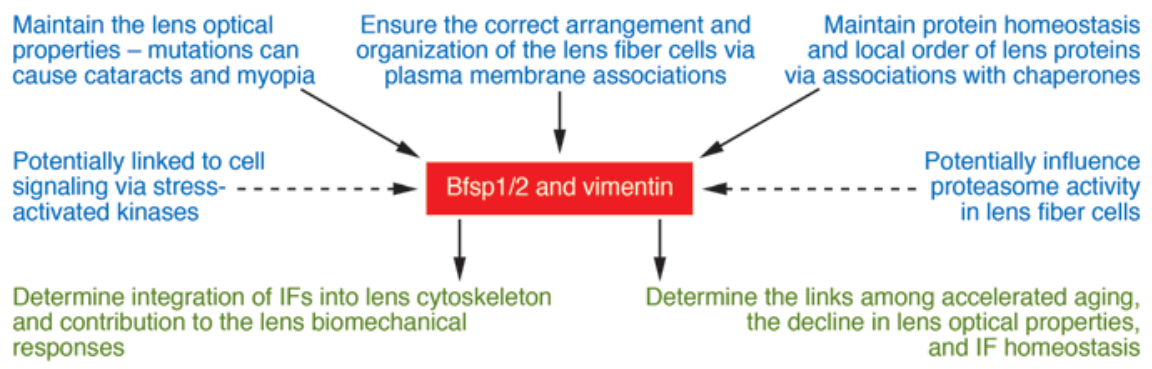

Figure 7

Summary of the conclusions (blue) and future research directions (green) for IFs and their function in the eye lens. 
Table 3

Candidate genes for cataract or loss of optical function via involvement with lenticular IFs

\begin{tabular}{|c|c|c|c|c|c|}
\hline Protein & Human gene symbol & $\begin{array}{l}\text { Human chromosomal } \\
\text { location }\end{array}$ & OMIM & Phenotype $^{A}$ & Referenc \\
\hline \multicolumn{6}{|c|}{ Soluble proteins } \\
\hline$\gamma$-Crystallin & CRYGB/CRYGC/CRYGE & $2 q 33-35$ & 123670,123680 & $\begin{array}{l}\text { Cataract caused by altered } \\
\text { aggregation when } \\
\text { mutated in mice }\end{array}$ & 103 \\
\hline \multicolumn{6}{|c|}{ Membrane or membrane-associated proteins } \\
\hline Lengsin & GLULD1 & $6 q 11$ & 611470 & & 72 \\
\hline Tropomodulin & TMOD4 & $1 q 12$ & 605834 & & 95 \\
\hline Ankyrin & ANK2 & $4 q 25-q 27$ & 106410 & Cataract when deleted in mice & 94 \\
\hline Desmoyokin & AHNAK & $11 q 12-q 13$ & 103390 & & 68 \\
\hline Periplakin & $P P L$ & $16 \mathrm{p} 13$ & 602871 & & 68,129 \\
\hline Periaxin & $P R X$ & $19 q 13.1-q 13.2$ & 605725 & & 68 \\
\hline Ezrin & VIL2 & $6 q 25-q 26$ & 123900 & & 68 \\
\hline Plectin & PLEC1 & $8 q 24$ & 601282 & & 68 \\
\hline Moesin & MSN & $X q 11.2-q 12$ & 309845 & & 68 \\
\hline Fodrin & SPTAN1/SPTBN1 & $9 q 33$ and $2 p 21$ & 18210,182970 & & 68 \\
\hline N-cadherin & $\mathrm{CDH} 2$ & $18 q 11.2$ & 114020 & & 68 \\
\hline Cadherin-11 & $\mathrm{CDH11}$ & $16 q 21-q 22.1$ & 600023 & & 68 \\
\hline$\alpha$-Catenin & CTNNA1 & $5 q 31$ & 116805 & & 68 \\
\hline$\beta$-Catenin & CTNNB & $3 p 22-p 21.3$ & 116806 & & 68 \\
\hline$\gamma$-Catenin & JUP & $17 q 21$ & 173325 & & 130 \\
\hline p120-catenin & CTNND1 & $11 q 11$ & 601045 & & 68 \\
\hline Vinculin & $V C L$ & $10 q 22.1-q 23$ & 193065 & & 68 \\
\hline
\end{tabular}

\begin{abstract}
AFor explanation, see ref. 57. AHNAK, AHNAK nucleoprotein; ANK2, ankyrin 2; CDH2, cadherin 2; CDH11, cadherin 11; CRYGB, $\gamma$ B-crystallin; CRYGC, $\gamma$ C-crystallin; CRYGE, $\gamma$ E-crystallin; CTNNA1, catenin (cadherin-associated protein), $\alpha 1,102 \mathrm{kDa}$; CTNNB, catenin (cadherin-associated protein), $\beta 1,88 \mathrm{kDa}$; CTNND1, catenin (cadherin-associated protein), $\delta 1$; GLULD1, glutamate-ammonia ligase (glutamine synthase) domain containing 1; JUP, junction plakoglobin; MSN, moesin; PLEC1, plectin; PPL, periplakin; PRX, periaxin; SPTAN1, spectrin, $\alpha$, non-erythrocytic 1 ( $\alpha$-fodrin); SPTBN1, spectrin, $\beta$, non-erythrocytic 1; TMOD4, tropomodulin 4; VCL, vinculin; VIL2, villin 2.
\end{abstract}

with $\alpha$-crystallins in the lens $(24,34)$ and that in other tissues $\alpha \mathrm{B}$-crystallin is fundamentally involved in IF function (reviewed in ref. 30) argues for an indirect interaction between beaded filaments and $\gamma$-crystallins at this stage.

The association of $\alpha$-crystallins with beaded filaments $(24,34)$ and with vimentin (47) in the lens is of key functional importance. Mutations in $\alpha \mathrm{A}$ - and $\alpha \mathrm{B}$-crystallin cause cataract (Table 2 ), but perhaps the most interesting aspect concerning the $\alpha \mathrm{B}$-crystallin mutations is that not all mutations have this effect. For instance, the first described mutation in $\alpha$ B-crystallin was R120G, which caused cataract and cardiomyopathy (104). The first mutation to be described that only caused a cataract and no cardiomyopathy was the 450delA mutation, which truncated the C-terminal domain and introduced a frameshift that produced a unique, unrelated C terminus (105). Just recently, other mutations that alter the $\mathrm{C}$ terminus have been found that give only myofibrillar myopathy (e.g., 464delCT; Q151X; ref. 106). At present it is unclear why there should be such differences in tissue susceptibility to these different mutations (107), but given the unusual assembly properties of beaded filaments and the unique lens filament formed by their association with beaded filament proteins, it is reasonable to expect this is a major factor.

\section{Conclusions and future directions}

We have summarized our conclusions and future directions in Figure 7 . The beaded filament is a distinctive feature of the eye lens and the component proteins, BFSP1 and BFSP2, are vital to the optical properties of the lens. The other major IF protein found in the eye lens is vimentin. Mutations in any one of these three IF proteins can cause cataract, demonstrating that they contribute to the normal maintenance of the eye lens. Analysis of one human BFSP2 mutation, E233del, revealed that sometimes the resulting cataract, although only visible to the trained expert, can be correlated with mild myopia. Therefore, as found in other IF systems, mutations in IF proteins in the eye lens can potentially predispose to, rather than cause, disease. This is of particular relevance for aging. IFs determine the optical properties of the lens, and this is achieved in two ways: first, beaded filaments ensure the correct arrangement and organization of the lens fiber cells, through their plasma membrane associations; second, lens IFs are closely associated with the major lens chaperones and therefore help maintain protein homeostasis, even in the crowded environment of the human lens, where cytoplasmic protein concentrations are in excess of $300 \mathrm{mg} / \mathrm{ml}$ and the life span of proteins is very much longer (up to 100 years) than in other tissues (in the absence of a nucleus and thus a genome, mature fibers cannot produce proteins, and the fiber cells themselves are not replaced in the lens, but have to function from birth for as long as the individual lives, or at least has a clear lens). Mutations in BFSP1, BFSP2, or vimentin can certainly induce a loss of these functions, but gain-of-function mutations could also potentially contribute to cataract formation. For instance, the vimentin E151K mutation has been shown to alter proteasome activity in lens fiber cells, and per- 
haps this is an example of a gain in function as a result of mutation. This identifies one of the important future directions for research into lens IFs - to confirm the cell biological basis of the cataract-causing mutations in vimentin as well as in BFSP1 and BFSP2. The second important research direction is to elucidate the molecular details of the interaction between IFs and the lens fiber plasma membrane. The third is to establish the role played by IFs in maintaining lens transparency and to detail the functional link with protein chaperones. The final direction is to scrutinize the potential links among the beaded filament structural proteins, accelerated aging, and the decline in lens optical properties.

1. Ishikawa, H., Bischoff, R., and Holtzer, H. 1968 Mitosis and intermediate-sized filaments in developing skeletal muscle. J. Cell Biol. 38:538-555.

2. Hyder, C.L., Pallari, H.M., Kochin, V., and Eriksson, J.E. 2008. Providing cellular signposts - post-translational modifications of intermediate filaments. FEBS Lett. 582:2140-2148.

3. Bloemendal, H., et al. 2004. Ageing and vision: structure, stability and function of lens crystallins. Prog. Biophys. Mol. Biol. 86:407-485.

4. Chepelinsky, A.B. 2009. Structural function of MIP/aquaporin 0 in the eye lens; genetic defects lead to congenital inherited cataracts. Handb. Exp. Pharmacol. 190:265-297.

5. Gong, X., Cheng, C., and Xia, C.H. 2007. Connexins in lens development and cataractogenesis. J. Membr Biol. 218:9-12.

6. Perng, M.D., Zhang, Q., and Quinlan, R.A. 2007. Insights into the beaded filament of the eye lens. Exp. Cell Res. 313:2180-2188.

7. Kuszak, J.R., Zoltoski, R.K., and Tiedemann, C.E 2004. Development of lens sutures. Int. J. Dev. Biol. 48:889-902.

8. Augusteyn, R.C. 2007. Growth of the human eye lens. Mol. Vis. 13:252-257.

9. Lynnerup, N., Kjeldsen, H., Heegaard, S., Jacobsen, C., and Heinemeier, J. 2008. Radiocarbon dating of the human eye lens crystallines reveal proteins without carbon turnover throughout life. PLoS ONE. 3:e1529.

10. Gibson, M.C., Patel, A.B., Nagpal, R., and Perrimon, N. 2006. The emergence of geometric order in proliferating metazoan epithelia. Nature. 442:1038-1041.

11. Ireland, M.E., et al. 2000. Up-regulation of novel intermediate filament proteins in primary fiber cells: an indicator of all vertebrate lens fiber differentiation? Anat. Rec. 258:25-33.

12. Sandilands, A., et al. 1995. Vimentin and CP49/ Filensin form distinct networks in the lens which are independently modulated during lens fibre cell differentiation. J. Cell Sci. 108:1397-1406.

13. Ramaekers, F.C.S., et al. 1980. Identification of the cytoskeletal proteins in lens-forming cells, a special epitheloid cell type. Exp. Cell Res. 127:309-327.

14. Bozanic, D., Bocina, I., and Saraga-Babic, M. 2006. Involvement of cytoskeletal proteins and growth factor receptors during development of the human eye. Anat. Embryol. (Berl.). 211:367-377.

15. Kasper, M., and Viebahn, C. 1992. Cytokeratin expression and early lens development. Anat. Embryol. (Berl.). 186:285-290.

16. Mokry, J., and Nemecek, S. 1998. Immunohistochemical detection of intermediate filament nestin. Acta Medica (Hradec Kralove). 41:73-80.

17. Yang, J., Bian, W., Gao, X., Chen, L., and Jing, N. 2000. Nestin expression during mouse eye and lens development. Mech. Dev. 94:287-291.

18. Tawk, M., et al. 2003. Synemin expression in developing normal and pathological human retina and lens. Exp. Neurol. 183:499-507.

19. Müller, M., et al. 2009. Dominant cataract forma-

\section{Acknowledgments}

The financial support of the Biotechnology and Biological Sciences Research Council (A. Landsbury) and the Royal Society (International Project to R.A. Quinlan and Q. Zhang) are gratefully acknowledged. We thank Terry Gibbons and Aileen Hutcheson for expert technical help.

Address correspondence to: Roy A. Quinlan, Biophysical Sciences Institute, School of Biological and Biomedical Sciences, Durham University, South Road, Durham DH1 3LE, United Kingdom. Phone: 44-191-334-1331; Fax: 44-191-334-1278; E-mail: r.a.quinlan@dur.ac.uk.

tion in association with a vimentin assembly disrupting mutation. Hum. Mol. Genet. 18:1052-1057.

20. Perng, M.D., et al. 2004. The intermediate filament systems in the eye lens. Methods Cell Biol. 78:597-624.

21. Sandilands, A., et al. 1995. Filensin is proteolytically processed during lens fiber cell differentiation by multiple independent pathways. Eur. J. Cell Biol. 67:238-253.

22. Masaki, S., and Watanabe, T. 1992. cDNA sequence analysis of CP94: rat lens fiber cell beaded-filament structural protein shows homology to cytokeratins. Biochem. Biophys. Res. Commun. 186:190-198.

23. Merdes, A., Brunkener, M., Horstmann, H., and Georgatos, S.D. 1991. Filensin: a new vimentinbinding, polymerization-competent, and membrane-associated protein of the lens fiber cell. J. Cell Biol. 115:397-410.

24. Quinlan, R.A., Carter, J.M., Sandilands, A., and Prescott, A.R. 1996. The beaded filament of the eye lens: an unexpected key to intermediate filament structure and function. Trends Cell Biol. 6:123-126.

25. Kim, S., and Coulombe, P.A. 2007. Intermediate filament scaffolds fulfill mechanical, organizational, and signaling functions in the cytoplasm. Genes Dev. 21:1581-1597.

26. Strnad, P., Zatloukal, K., Stumptner, C., Kulaksiz, H., and Denk, H. 2008. Mallory-Denk-bodies: lessons from keratin-containing hepatic inclusion bodies. Biochim. Biophys. Acta. 1782:764-774.

27. Perng, M.D., et al. 1999. Intermediate filament interactions can be altered by HSP27 and alphaBcrystallin. J. Cell Sci. 112:2099-2112.

28. Arcangeletti, M.C., et al. 1997. Modification of cytoskeleton and prosome networks in relation to protein synthesis in influenza A virus-infected LLC-MK2 cells. Virus Res. 51:19-34.

29. D’Alessandro, M., Russell, D., Morley, S.M., Davies, A.M., and Lane, E.B. 2002. Keratin mutations of epidermolysis bullosa simplex alter the kinetics of stress response to osmotic shock. J. Cell Sci. 115:4341-4351.

30. Quinlan, R. 2002. Cytoskeletal competence requires protein chaperones. Prog. Mol. Subcell. Biol. 28:219-233.

31. Michael, R., van Marle, J., Vrensen, G.F., and van den Berg, T.J. 2003. Changes in the refractive index of lens fibre membranes during maturation - impact on lens transparency. Exp. Eye Res. 77:93-99.

32. Ellis, R.J., and Minton, A.P. 2006. Protein aggregation in crowded environments. Biol. Chem. 387:485-497.

33. Maisel, H., and Perry, M.M. 1972. Electron microscope observations on some structural proteins of the chick lens. Exp. Eye Res. 14:7-12.

34. Carter, J.M., Hutcheson, A.M., and Quinlan, R.A. 1995. In vitro studies on the assembly properties of the lens beaded filament proteins: co-assembly with $\alpha$-crystallin but not with vimentin. Exp. Eye Res. 60:181-192.

35. Ireland, M., and Maisel, H. 1984. A cytoskeletal protein unique to lens fibre cell differentiation. Exp. Eye Res. 38:637-645.

36. Ireland, M., and Maisel, H. 1989. A family of lens fiber cell specific proteins. Lens Eye Toxic Res. 6:623-638.

37. FitzGerald, P.G., and Casselman, J. 1991. Immunologic conservation of the fiber cell beaded filament. Curr. Eye Res. 10:471-478.

38. Sawada, K., Agata, J., Eguchi, G., Quinlan, R.A., and Maisel, H. 1995. The predicted structure of CP49 and a variant thereof, $\mathrm{CP} 49_{\text {ins }}$, the first vertebrate cytopasmic intermediate filament protein with a lamin-like insertion in helix 1B. Curr. Eye Res. 14:545-553.

39. Hess, J.F., Casselman, J.T., and FitzGerald, P.G. 1993. cDNA analysis of the $49 \mathrm{kDa}$ lens fiber cell cytoskeletal protein: a new, lens-specific member of the intermediate filament family? Curr. Eye Res. 12:77-88.

40. Merdes, A., Gounari, F., and Georgatos, S.D. 1993. The $47-\mathrm{kD}$ lens-specific protein phakinin is a tailless intermediate filament protein and an assembly partner of filensin. J. Cell Biol. 123:1507-1516.

41. Gounari, F., et al. 1993. Bovine filensin possesses primary and secondary structure similarity to intermediate filament proteins. J. Cell Biol. 121:847-853.

42. Hess, J.F., Casselman, J.T., and Fitzgerald, P.G. 1996. Gene structure and cdna sequence identify the beaded filament protein cp49 as a highly divergent type-i intermediate filament protein. J. Biol. Chem. 271:6729-6735.

43. Masaki, S., and Quinlan, R.A. 1997. Gene structure and sequence comparisons of the eye lens specific protein, filensin, from rat and mouse: implications for protein classification and assembly. Gene. 201:11-20.

44. Quinlan, R.A. 1991. The soluble plasma membrane-cytoskeleton complexes and aging in the lens. In Eye lens membranes and aging. G.F.J.M. Vrensen and J. Clauwaert, editors. EURAGE. Leiden, The Netherlands. 171-184.

45. Goulielmos, G., et al. 1996. Filensin and phakinin form a novel type of beaded intermediate filaments and coassemble de-novo in cultured-cells. J. Cell Biol. 132:643-655

46. Sandilands, A., et al. 2004. Bfsp2 mutation found in mouse 129 strains causes the loss of CP49 and induces vimentin-dependent changes in the lens fibre cell cytoskeleton. Exp. Eye Res. 78:109-123.

47. Nicholl, I.D., and Quinlan, R.A. 1994. Chaperone activity of $\alpha$-crystallins modulates intermediate filament assembly. EMBO J. 13:945-953.

48. Conley, Y.P., et al. 2000. A juvenile-onset, progressive cataract locus on chromosome $3 \mathrm{q} 21-\mathrm{q} 22$ is associated with a missense mutation in the beaded filament structural protein-2. Am. J. Hum. Genet. 66:1426-1431.

49. Jakobs, P.M., et al. 2000. Autosomal-dominant congenital cataract associated with a deletion mutation in the human beaded filament protein gene BFSP2. Am.J. Hum. Genet. 66:1432-1436.

50. Sandilands, A., et al. 2003. Knockout of the intermediate filament protein CP49 destabilises the lens fibre cell cytoskeleton and decreases lens optical quality, but does not induce cataract. Exp. Eye Res. 76:385-391. 
51. Alizadeh, A., et al. 2004. Characterization of a mutation in the lens-specific CP49 in the 129 strain of mouse. Invest. Ophthalmol. Vis. Sci. 45:884-891.

52. Alizadeh, A., et al. 2002. Targeted genomic deletion of the lens-specific intermediate filament protein CP49. Invest. Ophthalmol. Vis. Sci. 43:3722-3727.

53. Zhang, Q., et al. 2004. Clinical description and genome wide linkage study of Y-sutural cataract and myopia in a Chinese family. Mol. Vis. 10:890-900.

54. Cui, X., et al. 2007. The E233del mutation in BFSP2 causes a progressive autosomal dominant congenital cataract in a Chinese family. Mol. Vis. 13:2023-2029.

55. Ma, X., et al. 2008. A new mutation in BFSP2 (G1091A) causes autosomal dominant congenital lamellar cataracts. Mol. Vis. 14:1906-1911.

56. Ramachandran, R.D., Perumalsamy, V., and Hejtmancik, J.F. 2007. Autosomal recessive juvenile onset cataract associated with mutation in BFSP1. Hum. Genet. 121:475-482.

57. Reddy, M.A., Francis, P.J., Berry, V., Bhattacharya, S.S., and Moore, A.T. 2004. Molecular genetic basis of inherited cataract and associated phenotypes. Surv. Ophthalmol. 49:300-315.

58. Truscott, R.J. 2009. Presbyopia. Emerging from a blur towards an understanding of the molecula basis for this most common eye condition. Exp. Eye Res. 88:241-247.

59. Tong, L., Wong, E.H., Chan, Y.H., and Balakrishnan, V. 2002. A multiple regression approach to study optical components of myopia in Singapore school children. Ophthalmic Physiol. Opt. 22:32-37.

60. van Alphen, G. 1961. On emmetropia and ametropia. Opt. Acta (Lond.). 142(Suppl.):1-92.

61. Mutti, D.O., et al. 2007. Refractive error, axial length, and relative peripheral refractive error before and after the onset of myopia. Invest. Ophthalmol. Vis. Sci. 48:2510-2519.

62. Kuszak, J.R., Zoltoski, R.K., and Sivertson, C. 2004 Fibre cell organization in crystalline lenses. Exp. Eye Res. 78:673-687.

63. Andrew, T., et al. 2008. Identification and replication of three novel myopia common susceptibility gene loci on chromosome 3q26 using linkage and linkage disequilibrium mapping. PLoS Genet. 4:e1000220.

64. Hess, J.F., Casselman, J.T., and Fitzgerald, P.G. 1995. Chromosomal locations of the genes for the beaded filament proteins $\mathrm{cp}-115$ and $\mathrm{cp}-47$. Curr. Eye Res. 14:11-18

65. Lu, J.Y., Mohammed, T.A., Donohue, S.T., and AlGhoul, K.J. 2008. Distribution of basal membrane complex components in elongating lens fibers. Mol. Vis. 14:1187-1203.

66. Ireland, M.E., Klettner, C., and Nunlee, W. 1993. Cyclic AMP-mediated phosphorylation and insolubilization of a 49-kDa cytoskeletal marker protein of lens fiber terminal differentiation. Exp. Eye Res. 56:453-461.

67. Franke, W.W., Kapprell, H.P., and Cowin, P. 1987. Plakoglobin is a component of the filamentous subplasmalemmal coat of lens cells. Eur. J. Cell Biol. 43:301-315

68. Straub, B.K., et al. 2003. A novel cell-cell junction system: the cortex adhaerens mosaic of lens fiber cells. J. Cell Sci. 116:4985-4995.

69. Yoon, K.H., and FitzGerald, P.G. 2009. Periplakin interactions with lens intermediate and beaded filaments. Invest. Ophthalmol. Vis. Sci. 50:1283-1289.

70. Leung, C.L., Green, K.J., and Liem, R.K. 2002. Plakins: a family of versatile cytolinker proteins. Trends Cell Biol. 12:37-45.

71. Roper, K., Gregory, S.L., and Brown, N.H. 2002. The 'spectraplakins': cytoskeletal giants with characteristics of both spectrin and plakin families. J. Cell Sci. 115:4215-4225.

72. Wyatt, K., et al. 2008. A role for lengsin, a recruited enzyme, in terminal differentiation in the vertebrate lens. J. Biol. Chem. 283:6607-6615.

73. Bassnett, S. 2002. Lens organelle degradation. Exp.
Eye Res. 74:1-6.

74. Alizadeh, A., et al. 2003. Targeted deletion of the lens fiber cell-specific intermediate filament protein filensin. Invest. Ophthalmol. Vis. Sci. 44:5252-5258.

75. Marcantonio, J.M. 1992. Susceptibility of the bovine lens $115 \mathrm{kDa}$ beaded filament protein to degradation by calcium and calpain. Curr. Eye Res. 11:103-108.

76. Oka, M., Kudo, H., Sugama, N., Asami, Y., and Takehana, M. 2008. The function of filensin and phakinin in lens transparency. Mol. Vis. 14:815-822.

77. Truscott, R.J. 2005. Age-related nuclear cataractoxidation is the key. Exp. Eye Res. 80:709-725.

78. Evans, J.R., Rauf, A., Aihie Sayer, A., Wormald, R.P., and Cooper, C. 1998. Age-related nuclear lens opacities are associated with reduced growth before 1 year of age. Invest. Ophthalmol. Vis. Sci. 39:1740-1744

79. Hejtmancik, J.F., and Kantorow, M. 2004. Molecular genetics of age-related cataract. Exp. Eye Res. 79:3-9

80. Simirskii, V.N., Lee, R.S., Wawrousek, E.F., and Duncan, M.K. 2006. Inbred FVB/N mice are mutant at the cp49/Bfsp2 locus and lack beaded filament proteins in the lens. Invest. Ophthalmol. Vis. Sci. 47:4931-4934.

81. Gerido, D.A., Sellitto, C., Li, L., and White, T.W. 2003. Genetic background influences cataractogenesis, but not lens growth deficiency, in Cx50-knockout mice. Invest. Ophthalmol. Vis. Sci. 44:2669-2674.

82. Oda, S., Watanabe, K., Fujisawa, H., and Kameyama, Y. 1980. Impaired development of lens fibers in genetic microphthalmia, eye lens obsolescence, Elo, of the mouse. Exp. Eye Res. 31:673-681.

83. Shiels, A., King, J.M., Mackay, D.S., and Bassnett, S. 2007. Refractive defects and cataracts in mice lacking lens intrinsic membrane protein-2. Invest. Ophthalmol. Vis. Sci. 48:500-508.

84. Lindsey Rose, K.M., et al. 2006. The C terminus of lens aquaporin 0 interacts with the cytoskeletal proteins filensin and CP49. Invest. Ophthalmol. Vis Sci. 47:1562-1570.

85. Colucci-Guyon, E., et al. 1994. Mice lacking vimentin develop and reproduce without an obvious phenotype. Cell. 79:679-694.

86. Capetanaki, Y., Smith, S., and Heath, J.P. 1989. Overexpression of the vimentin gene in transgenic mice inhibits normal lens cell differentiation. J. Cell Biol. 109:1653-1664.

87. Bornheim, R., et al. 2008. A dominant vimentin mutant upregulates Hsp70 and the activity of the ubiquitin-proteasome system, and causes posterior cataracts in transgenic mice. J. Cell Sci. 121:3737-3746.

88. FitzGerald, P.G. 1990. Methods for the circumvention of problems associated with the study of the ocular lens plasma membrane-cytoskeleton complex. Curr. Eye Res. 9:1083-1097.

89. Franke, W.W., Kapprell, H.-P., and Cowin, P. 1987. Plakoglobin is a component of the filamentous subplasmalemmal coat of lens cells. Eur. J. Cell Biol. 43:301-315.

90. Sonnenberg, A., Rojas, A.M., and de Pereda, J.M 2007. The structure of a tandem pair of spectrin repeats of plectin reveals a modular organization of the plakin domain. J. Mol. Biol. 368:1379-1391.

91. Boczonadi, V., McInroy, L., and Maatta, A. 2007. Cytolinker cross-talk: periplakin $\mathrm{N}$-terminus interacts with plectin to regulate keratin organisation and epithelial migration. Exp. Cell Res. 313:3579-3591.

92. Georgatos, S.D., Weaver, D.C., and Marchesi, V.T. 1985. Site specificity in vimentin-membrane interactions: intermediate filament subunits associate with the plasma membrane via their head domains. J. Cell Biol. 100:1962-1967.

93. Dola, A., Katar, M., Hussain, P., and Maisel, H. 1990. Ankyrin of the ocular lens. Ophthalmic Res.
22:295-301.

94. More, M.I., Kirsch, F.P., and Rathjen, F.G. 2001. Targeted ablation of NrCAM or ankyrin-B results in disorganized lens fibers leading to cataract formation. J. Cell Biol. 154:187-196.

95. Fischer, R.S., Quinlan, R.A., and Fowler, V.M. 2003. Tropomodulin binds to filensin intermediate filaments. FEBS Lett. 547:228-232.

96. Allen, D.P., Low, P.S., Dola, A., and Maisel, H. 1987. Band 3 and ankyrin homologues are present in eye lens: evidence for all major erythrocyte membrane components in same non-erythroid cell. Biochem. Biophys. Res. Commun. 149:266-275.

97. Pontoriero, G.F., et al. 2009. Co-operative roles for E-cadherin and $\mathrm{N}$-cadherin during lens vesicle separation and lens epithelial cell survival. Dev. Biol. 326:403-417.

98. Maatta, A., DiColandrea, T., Groot, K., and Watt, F.M. 2001. Gene targeting of envoplakin, a cytoskeletal linker protein and precursor of the epidermal cornified envelope. Mol. Cell. Biol. 21:7047-7053.

99. Kaye, L.D., Rothner, A.D., Beauchamp, G.R., Meyers, S.M., and Estes, M.L. 1992. Ocular findings associated with neurofibromatosis type II. Ophthalmology. 99:1424-1429.

100.Giovannini, M., et al. 2000. Conditional biallelic $\mathrm{Nf} 2$ mutation in the mouse promotes manifestations of human neurofibromatosis type 2 . Genes Dev. 14:1617-1630.

101.Lin, H., Hejtmancik, J.F., and Qi, Y. 2007. A substitution of arginine to lysine at the $\mathrm{COOH}$-terminus of MIP caused a different binocular phenotype in a congenital cataract family. Mol. Vis. 13:1822-1827.

102.Fan, J., et al. 2005. Specific interaction between lens MIP/Aquaporin-0 and two members of the gamma-crystallin family. Mol. Vis. 11:76-87.

103.Sandilands, A., et al. 2002. Altered aggregation properties of mutant gamma-crystallins cause inherited cataract. EMBO J. 21:6005-6014.

104.Vicart, P., et al. 1998. A missense mutation in the alphaB-crystallin chaperone gene causes a desminrelated myopathy. Nat. Genet. 20:92-95.

105.Berry, V., et al. 2001. Alpha-B crystallin gene (CRYAB) mutation causes dominant congenital posterior polar cataract in humans. Am. J. Hum. Genet. 69:1141-1145.

106.Selcen, D., and Engel, A.G. 2003. Myofibrillar myopathy caused by novel dominant negative alpha B-crystallin mutations. Ann. Neurol. 54:804-810.

107. Hayes, V.H., Devlin, G., and Quinlan, R.A. 2008 Truncation of alphaB-crystallin by the myopathycausing Q151X mutation significantly destabilizes the protein leading to aggregate formation in transfected cells. J. Biol. Chem. 283:10500-10512.

108.Zhou, M., Leiberman, J., Xu, J., and Lavker, R.M. 2006. A hierarchy of proliferative cells exists in mouse lens epithelium: implications for lens maintenance. Invest. Ophthalmol. Vis. Sci. 47:2997-3003.

109. Taylor, V.L., et al. 1996. Morphology of the normal human lens. Invest. Ophthalmol. Vis. Sci. 37:1396-1410.

110.Quinlan, R.A., Brenner, M., Goldman, J.E., and Messing, A. 2007. GFAP and its role in Alexander disease. Exp. Cell Res. 313:2077-2087.

111. Brunkener, M., and Georgatos, S.D. 1992. Membrane-binding properties of filensin, a cytoskeletal protein of the lens fibre cells. J. Cell Sci. 103:709-718.

112.Pras, E., et al. 2000. A nonsense mutation (W9X) in CRYAA causes autosomal recessive cataract in an inbred Jewish Persian family. Invest. Ophthalmol. Vis. Sci. 41:3511-3515.

113.Hansen, L., et al. 2007. Genetic heterogeneity in microcornea-cataract: five novel mutations in CRYAA, CRYGD, and GJA8. Invest. Ophthalmol. Vis. Sci. 48:3937-3944.

114.Devi, R.R., et al. 2008. Crystallin gene mutations in Indian families with inherited pediatric cataract. Mol. Vis. 14:1157-1170.

115.Graw, J., Klopp, N., Illig, T., Preising, M.N., and 
Lorenz, B. 2006. Congenital cataract and macular hypoplasia in humans associated with a de novo mutation in CRYAA and compound heterozygous mutations in P. Graefes Arch. Clin. Exp. Ophthalmol. 244:912-919.

116.Mackay, D.S., Andley, U.P., and Shiels, A. 2003. Cell death triggered by a novel mutation in the alphaAcrystallin gene underlies autosomal dominant cataract linked to chromosome 21q. Eur. J. Hum. Genet. 11:784-793.

117. Khan, A.O., Aldahmesh, M.A., and Meyer, B. 2007. Recessive congenital total cataract with microcornea and heterozygote carrier signs caused by a novel missense CRYAA mutation (R54C). Am. J. Ophthalmol. 144:949-952.

118. Santhiya, S.T., et al. 2006. Identification of a novel, putative cataract-causing allele in CRYAA (G98R) in an Indian family. Mol. Vis. 12:768-773.

119. Litt, M., et al. 1998. Autosomal dominant congenital cataract associated with a missense mutation in the human alpha crystallin gene CRYAA. Hum. Mol. Genet. 7:471-474.
120.Beby, F., et al. 2007. New phenotype associated with an Arg116Cys mutation in the CRYAA gene: nuclear cataract, iris coloboma, and microphthalmia. Arch. Ophthalmol. 125:213-216.

121. Vanita, V., et al. 2006. A novel fan-shaped cataractmicrocornea syndrome caused by a mutation of CRYAA in an Indian family. Mol. Vis. 12:518-522.

122.Richter, L., et al. 2008. Clinical variability of autosomal dominant cataract, microcornea and corneal opacity and novel mutation in the alpha A crystallin gene (CRYAA). Am. J. Med. Genet. A. 146:833-842.

123.Gu, F., et al. 2008. A novel mutation in AlphaAcrystallin (CRYAA) caused autosomal dominant congenital cataract in a large Chinese family. Hum. Mutat. 29:769.

124.Liu, M., et al. 2006. Identification of a CRYAB mutation associated with autosomal dominant posterior polar cataract in a Chinese family. Invest. Ophthalmol. Vis. Sci. 47:3461-3466.

125.Liu, Y., et al. 2006. A novel alphaB-crystallin mutation associated with autosomal dominant con- genital lamellar cataract. Invest. Ophthalmol. Vis. Sci. 47:1069-1075.

126.Inagaki, N., et al. 2006. Alpha B-crystallin mutation in dilated cardiomyopathy. Biochem. Biophys. Res. Commun. 342:379-386.

127.Gu, F., et al. 2007. A novel mutation in major intrinsic protein of the lens gene (MIP) underlies autosomal dominant cataract in a Chinese family. Mol. Vis. 13:1651-1656.

128. Berry, V., Francis, P., Kaushal, S., Moore, A., and Bhattacharya, S. 2000. Missense mutations in MIP underlie autosomal dominant 'polymorphic' and lamellar cataracts linked to 12q. Nat. Genet. 25:15-17.

129. Yoon, K.-H., and Fitzgerald, P.G. 2008. Periplakin serves as a linker for both vimentin and the highly divergent beaded filament proteins in the ocular lens. Invest. Ophthalmol. Vis. Sci. doi:10.1167/iovs.08-2894.

130.Leonard, M., Chan, Y., and Menko, A.S. 2008. Identification of a novel intermediate filament-linked $\mathrm{N}$-cadherin/gamma-catenin complex involved in the establishment of the cytoarchitecture of differentiated lens fiber cells. Dev. Biol. 319:298-308. 